\title{
AN ANALYSIS OF THE RELATIONSHIP BETWEEN EARNINGS AND CORPORATE TAXES ON DIVIDEND POLICY OF COMPANIES IN SRI-KEHATI INDEX
}

\author{
Etheldreda Gladys Salvatori $^{1}$, Robiyanto Robiyanto ${ }^{2}$, Harijono Harijono ${ }^{3}$ \\ 1,2,3 Fakultas Ekonomika dan Bisnis, Universitas Kristen Satya Wacana, Salatiga, Indonesia \\ e-mail: ${ }^{1}$ gladys.etheldreda@gmail.com; ${ }^{2}$ robiyanto.robiyanto@uksw.edu; ${ }^{3}$ harijono.harijono@uksw.edu
}

Received May 28, 2020; accepted June 17, 2020; published July 1, 2020.

\begin{abstract}
Objective: This study examines the effect of earnings and corporate taxes role on the company's dividend policy in the SRI-KEHATI Index. In this research, dividend policy means dividends paid proportion to shareholders. Earnings are estimated by four financial ratios namely contributed capital ratio, prior year-earnings, sales growth, and return on assets. Research Design \& Methods: The sample is taken according to purposive sampling with the criteria of the consistency of the company listed in the SRI-KEHATI Index during 2014-2017 and routinely distributes annual dividends, finally 14 companies are taken from 33 companies. Panel data were examined with the assistance of Eviews 9.0 software. Data collected from the company's financial statements and measured using a formula adopted from earlier research. Findings: Empirical results found that capital ratio, prior year-earnings, sales growth, and corporate taxes did not significantly affect the dividend payout ratio. While return on assets has a positive effect on dividend payout ratio. Companies that grow well will need more funds to cover their financing and try to keep up their income proportion, one way is to pay a constant dividend, lower, or even zero dividends. Limitations \& Recommendations: This finding recommends that investors should pay attention to company profitability by measuring return on assets. Future research can use the new stock index's constituents such as IDX High Dividend 20 and include other factors that indicated to determine dividend policy. Contribution \& Value Added: This result contributes to the financial literature, especially related to the dividend policy of public listed companies in Indonesia. Practically, investors can use this result as additional information in investment decisions.
\end{abstract}

Keywords: corporate taxes; earnings; dividend payout ratio; dividend policy; SRI-KEHATI Index. JEL codes: H25, G32, G35

Article type: research paper

\section{INTRODUCTION}

The practice of dividend payments has been a subject of debate in financial literature over the past two decades (DeAngelo et al., 2004; Gill et al., 2010). Theories and results of research on corporate dividend policy have developed with various theoretical models that describe the factors considered by managers to decide dividend policies and investment decisions for investors. In the context of this study, dividend policy means the manager's policy in determining the number of dividends paid within a certain time. Miller \& Modigliani (1961) shocking statement in his paper, dismissed by the results of recent research because it was less relevant to the conventional policies followed by managers at this time. Some financial practitioners and academics agree that a well-managed dividend policy results in changes in stock prices (Hashemijoo et al., 2012; Hussainey et al., 2011) and increases the value of the company (Anton, 2016; Rizqia \& Sumiati, 2013). 
In an efficient capital market, the investor wants a high dividend distribution for the funds he or she has invested. Dividends are twice as valuable as capital gains in uncertainty and asymmetric information (Al-Malkawi, 2007), therefore, investors tend to choose dividends to get higher returns (Arif \& Akbar, 2013). Usually, investors pay attention to stocks that are included in the stock price index, because they will provide information to investors about the stock's performance and overall market (Indonesia Stock Exchange (IDX), 2019). Until 2019, IDX recorded 14 listed stock indices namely the Composite Stock Price Index (CSPI) and 13 sectoral stock, LQ45 Index, IDX30 Index, Kompas100 Index, Indonesia Sharia Stock Index (ISSI), Jakarta Islamic Index (JII), BUSINESS -27 Index, PEFINDO25 Index, SRIKEHATI Index, infobank15 Index, Sminfra1 8 Index, MNC36 Index, Investor33 Index, and Individual Index. This study focuses on companies included in the SRI-KEHATI Index during 2014-2017. This index considers 25 companies with best practices in paying attention to the environment, social, and corporate governance. While corporate governance quality affects the policy policies set by the company (Adjaoud \& Ben-Amar, 2010; Setiawan \& Phua, 2013).

The amount of dividends paid depends on the policies that the company follows through certain considerations, one of which is corporate income (DeAngelo et al., 2006; Jabbouri, 2016; Thanatawee, 2011) and corporate tax (Gill et al., 2010; Hutagaol-Martowidjojo et al., 2019; Osegbue et al., 2014). It seems that the company's dividend policy and dividend payment influenced by its life cycle, known as the life cycle theory (DeAngelo et al., 2006; Thanatawee, 2011). This theory examines the involvement of earned/contributed capital in dividend payments. Earned/contributed capital measured by retained earnings to total equity or retained earnings to total assets (DeAngelo et al., 2006). Jabbouri (2016) states in his research results that the company's current earnings determine policy and dividend payout ratio. When the current retained earnings are higher than in the previous period, it is allowing them to pay higher dividends.

The company cannot be exempted from the obligation to pay taxes. Revenue is directly proportional to corporate tax payment and effects company profitability. The nominal tax paid by a company is not always the same, this corresponds to the amount of gross income generated by the company at a certain time. Tax withheld from corporate income will reduce profit after tax (Demirgüç-Kunt \& Huizinga, 1999; Dietrich \& Wanzenried, 2014). Thus the company's management will consider taxes in setting dividend policies. Corporate tax does not significantly affect the dividend payout ratio of the manufacturing sector. However, in the service sector, corporate tax is a significant determinant of the dividend payout ratio (Hutagaol-Martowidjojo et al., 2019).

Several articles are examining the factors that influence dividends in Indonesian companies as mentioned by Baker \& Powell (2012); Rizqia \& Sumiati (2013); Ahmad \& Wardani (2014); and Hutagaol-Martowidjojo et al. (2019), such as ROA, corporate taxes, capital ratio, prior year-earnings, and sales growth. Baker \& Powell (2012); Rizqia \& Sumiati (2013); Ahmad \& Wardani (2014); and Hutagaol-Martowidjojo et al. (2019) examine the effect of profitability that proxies by ROA in determining dividend payout ratios. The contributed capital ratio refers to the investment activities of shareholders in a corporation, the higher this ratio will lead to a higher dividend. While, prior yearearnings are profits from previous operating periods that the company retained for reinvested in the business, and will affect dividend positively, same as ROA and sales growth.

This study is a replication of several previous studies and focused on the factors that affected dividend payments of companies listed in the SRI-KEHATI Index. To the best of authors' knowledge, limited studies been done by using these companies. This study aims to examine the effect of corporate income and tax on company dividend policies that included in the SRI-KEHATI Index in 2014-2017. The results of this study are expected to contribute to the financial literature, especially related to the dividend policy of go-public companies in Indonesia. In practice, investors can use this result as more information in investment decisions. 


\section{LITERATURE REVIEW}

\section{Dividend Signalling Theory}

Signals are company actions that give indications or signs to stakeholders about the company's prospects (Brigham \& Houston, 2016). Dividend signaling theory is a model that explains why companies use dividends to give signals even if they incur losses while implementing them. For companies with good prospects, they can compensate these costs (dividend payments) through gradual stock expenditures at increasing prices. But for companies, that less successful cannot do the same. Thus, giving signals through dividend value gives positive results for the company (Dagys \& Mladjenovic, 2010).

\section{Bird in Hand Theory}

The bird in the hand theory explains that dividends are preferred over capital gains because they are considered more certain. So it can be indicated that investors will be more pleased with the company that makes dividend payments. Dividend payments can be made if the company is performing well.

\section{Relationship of Contributed Capital Ratio to Dividend Payout Ratio}

The contributed capital ratio is a ratio that explains the number of capital stock payments contributed to corporations by shareholders for use in a company business (Munawir, 2004). Needles, Powers, \& Crosson (2010) stated that contributed capital refers to the investment activities of shareholders in a corporation. He also said in his writings that managing contributed capital properly is important for corporation financing, because it relates to equity financing issues and to manage it, required an understanding of corporate organizations, familiar with dividend policy and evaluating performance.

DeAngelo et al. (2006) observed that the company's decision to pay a dividend is highly depend on the company's income. In their paper, they measure income with earned/contributed capital, i.e. retained earnings to total equity (RE/TE) or retained earnings to total assets (RE/TA). The results show that companies with low RE/TE are in the "capital injection" stage while companies with high RE/TE show better capital. There is an involvement of capital structure decisions in the choice of dividend payment methods (Allen \& Michaely, 2003).

H1: Contributed capital ratio has a significant positive effect on the dividend payout ratio

\section{Relationship of Prior year-earnings to Dividend Payout Ratio}

Prior year-earnings are profits from previous operating periods that the company retained for reinvested in the business (Dagys \& Mladjenovic, 2010). The profit is also owned by the shareholders, but management has the choice to decide whether to pay the dividend or not. In general, management thinks that they are more effective in reinvesting their money in the business than paying it to shareholders. However, a decent company, shareholders may want the highest possible profits and grow. This is a capital allocation game (Boquist et al., 1998; Dagys \& Mladjenovic, 2010; Fleischer, 1969). Jabbouri (2016) also believes that the previous year's income was the main driver of dividend payments in the current year. The statement was also proven by Allen \& Michaely (1995), that the dividend policy is influenced by the capital of the company.

Arnott \& Asness (2003) observed the prospect of future dividend payout ratios by examining the company's income 10 years earlier. The results prove that the previous year's income encourages companies to increase their revenue, companies will pay more when they know the bright prospects of their future earnings are bright and less when the prospect of dim earnings (Arnott \& Asness, 2003). Similar results were also conveyed by Kighir, Omar, \& Mohamed (2015), that the main determinants of changes in dividend payment policies were cash flow and earnings. Although they consider the previous year's cash flow more important than previous year's earnings in the payment policy, this does not change the findings that the previous year's earning affects the dividend payment policy. The contents of a company's dividend policy depend on past earnings and dividend-payment records (Charitou et al., 2010).

$\mathrm{H} 2$ : Prior year-earnings has a significant positive effect on the dividend payout ratio 


\section{Relationship of Sales Growth to Dividend Payout Ratio}

Sales growth is one measure of company growth. In dividend payment decisions, sales growth is important for management consideration. There are differences of opinion from some financial experts about the relationship of sales growth to dividend payout ratios, some of which are positive (Ishaq et al., 2018; Myers \& Bacon, 2004; Tahir \& Mushtaq, 2016) and some have stated the opposite (Gill et al., 2010; Imran, 2011; Khan \& Ashraf, 2014). Companies that grow rapidly tend to be more secure in obtaining funding to finance their business activities than companies that grow slowly. According to Brigham \& Houston (2016), companies with relatively stable sales are easier to obtain more funding and bear a higher fixed burden than companies with unstable sales.

High-growth companies have greater investment needs to fund new projects (Gill et al., 2010; Khan \& Ashraf, 2014). To ensure access to external capital, the company builds a good reputation through higher dividend payments (Myers \& Bacon, 2004). High dividend payments will reduce agent cost equity but will increase transaction costs related to internal funding (Hatta, 2002). For companies with high sales growth rates tend to distribute dividends more consistently than companies with low sales growth rates (Hatta, 2002). Tahir \& Mushtaq (2016) finding reject his hypothesis, the results showed sales growth and dividend payments were positively related and supported the dividend signaling theory.

H3: Sales growth has a significant positive effect on the dividend payout ratio

\section{Relationship of Corporate Taxes to Dividend Payout Ratio}

This study focused on the corporate level rather than the individual level. So, the explanation in this section done by using the corporate perspective. Gill et al. (2010) found a positive relationship between corporate tax and dividend payout ratios in the manufacturing sector in the US capital market but the relationship between corporate tax and dividend payout ratios was negative in the service sector. According to Hutagaol-Martowidjojo et al. (2019), for manufacturing companies, corporate tax is an insignificant determinant of the dividend payout ratio, but in the service sector, corporate tax is a significant determinant of the dividend payout ratio. Osegbue et al. (2014) in their study of determining dividend payout ratios found that corporate taxes had a positive effect on dividend payout ratios. They find that there is strong empirical evidence that companies paying dividends above the legal mandatory level present different determinants from those that only pay the minimum level. For managers, maximizing shareholders' value requires taking into account the consequences of the taxation when designing financial policies for the firm.

H4: Corporate taxes have a significant positive effect on the dividend payout ratio

\section{Relationship of Return on Assets to Dividend Payout Ratio}

Return on assets (ROA) is a familiar ratio for calculating profitability. This ratio is used to measure returns on total assets by dividing net income from total assets (Brigham \& Houston, 2016). Through ROA, readers of the company's financial statements can predict the company's ability to generate net income with assets owned (Pranata \& Pujiati, 2015). According to Khadafi, Heikal, \& Ummah (2014), ROA is the ratio between net earnings after tax to total assets. Return on assets (ROA) shows the effectiveness of companies utilizing funds for the benefit of the company. The higher ratio the more profitable the company is in relative terms.

Profitability is a factor often considered by directors in paying dividends. It has been proven by previous empirical studies that profitability is one of the main determinants of dividend payment decisions (Gill et al., 2010; Khan \& Ashraf, 2014; Tahir \& Mushtaq, 2016). Profitability affects the dividend policy because dividends are the amount of money paid by companies to shareholders that sourced from the company's net profit. Profitability calculated through ROA affects the level of dividend payments. Ahmad \& Wardani (2014) found that there is a positive relationship between profitability and dividend payments.

H5: Return on assets has a significant positive effect on the dividend payout ratio

JMER, 2020, 01(1), 1-12 


\section{Theoretical Framework}

This study wants to prove the causal relationship between contributed capital ratio, prior year-earnings, sales growth, corporate taxes, and return on assets to the dividend payout ratio of companies that included in the SRI-KEHATI index calculated during 2014-2017. Thus, the research framework is drawn in Figure 1.

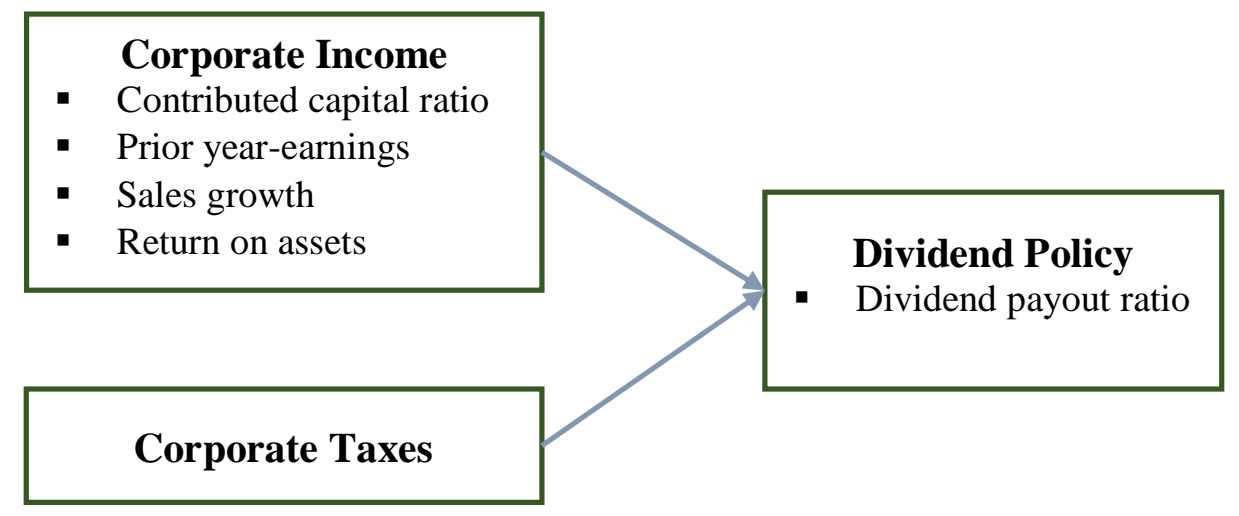

Figure 1. Theoretical Framework

\section{METHODS}

\section{Data and Sample Selection}

This study is a conclusive study that uses quantitative data collected from the company's financial statements that are consistently included in the SRI-KEHATI Index from 2014 to 2017. Secondary data are obtained from the Indonesia Stock Exchange (IDX) website page, www.idx.co.id. The study population is all companies included in the SRI-KEHATI Index. The sample is taken according to purposive sampling with criteria as a consistent company in the SRI-KEHATI Index during the 20142017 periods and routinely distributes dividends annually. The number of samples that meet the sampling criteria is 14 companies out of 33 companies.

\section{Operational Variables}

Research variables measured using formulas that have become theories and often used in previous studies. Operational definitions of research variables seen in Table 1 below.

Table 1. Measurement Scale of Research Variables

\begin{tabular}{|c|c|c|c|}
\hline Variable & Symbol & Proxy & Measurement \\
\hline Dividend policy & DPR & Dividend payout ratio & Dividend per share \\
\hline \multirow{6}{*}{$\begin{array}{l}\text { Corporate } \\
\text { Income }\end{array}$} & & & Earning per share \\
\hline & CCR & Contributed capital ratio & Retained earnings at firm - year $_{\mathrm{t}}$ \\
\hline & & & Total book value of equity at firm - year $_{t}{ }^{\lambda}$ \\
\hline & PYE & Prior year-earnings & Profit after tax in the previous year \\
\hline & SGW & Sales growth & $\underline{\text { Current sales }- \text { Previous sales }} \times 100 \%$ \\
\hline & ROA & Return on assets & $\begin{array}{c}\text { Previous sales } \\
\text { Net income after taxes at firm }- \text { year }_{\mathrm{t}} \\
\text {. }\end{array} 100 \%$ \\
\hline Corporate Taxes & CTX & Corporate income taxes & $\begin{array}{l}\text { Total assets at firm }- \text { year }_{\mathrm{t}} \\
\text { Current total corporate income taxes includes } \\
\text { deferred taxes at that year }\end{array}$ \\
\hline
\end{tabular}

\section{Variables Explanation}

The dependent variable of this study is the dividend policy measured by dividend payout ratio (DPR), dividend per share to earnings per share. The studies of Gill et al. (2010); Hussainey et al. (2011); Khan \& Ashraf (2014); Tahir \& Mushtaq (2016); Ahmed (2015); and Hutagaol-Martowidjojo et al. (2019) measures the dividend policy by calculating the dividend payout ratio. The independent variable is earning and corporate tax (CTX). The company's earning measured in four financial ratios, namely 
contributed capital ratio (CCR), prior year-earnings (PYE), sales growth (SGW), and return on assets (ROA). To measure CCR, this study uses a proxy from DeAngelo et al. (2006) by dividing retained earnings to total book value of equity at that year. This formula was also adopted by HutagaolMartowidjojo et al. (2019) and Thanatawee (2011).

PYE is the number of earnings after tax in the previous year and CTX is the current total corporate income taxes including deferred taxes that year. Both proxies refer to the formula used by HutagaolMartowidjojo et al. (2019). Percentage of change in current sales from the previous period to measure the company's sales growth (SGW). This formula is consistent with Gill et al. (2010); Tahir \& Mushtaq, (2016); and Imran (2011). Whereas ROA calculated by dividing net income after taxes to total assets that year. The same proxy was used by DeAngelo et al. (2006); Thanatawee (2011); Rizqia \& Sumiati (2013); and Ahmed (2015).

\section{Empirical Model}

The multiple regression equation in this study is:

$$
D P R_{i t}=\alpha_{0}+\beta_{1} C C R_{i t}+\beta_{2} P Y E_{i t}+\beta_{3} S G W_{i t}+\beta_{4} C T X_{i t}+\beta_{5} R O A_{i t}+\varepsilon_{i t}
$$

where, $\alpha$ is a constant while $\beta_{1}, \beta_{2}, \beta_{3}, \beta_{4}$, and $\beta_{5}$ are variable coefficients of CCR, PYE, SGW, CTX, and ROA.

The equation above is a multiple regression model of several independent variables and one dependent variable. Multiple linear regression models estimation aims to predict the parameters of the regression model, namely the constant value $(\alpha)$ and the regression coefficient $\left(\beta_{\mathrm{i}}\right)$.

\section{Data Analysis Technique}

The analysis technique used in this study uses panel regression data with Eviews 9.0 software. Panel data is a combination of both cross-section and time-series (Winarno, 2017). In data processing, data tabulation using Excel to avoid calculation errors and make it easy to enter data into Eviews for analysis. The analysis passed included normality test, classic assumption test consisting of multicollinearity, autocorrelation, and heteroscedasticity, multiple linear regression analysis, and finally hypothesis testing.

\section{FINDINGS}

\section{Descriptive Statistics}

Descriptive statistics for all variables shown in Table 2. From Table 2, it can be seen that the average DPR is 0.387 . The maximum value is 1 , while the minimum is 0.080 with the standard deviation is 0.199 . The average CCR variable is 20985.393 , with maximum value is 217649 and the minimum value 1487, with a standard deviation, is 41847.583. The average value of PYE is 7695524.286, the maximum value is 26227991 , the minimum value is 171784 , and the standard deviation is 8295393.933 . For SGW variable, the average value is 0.122 , the maximum value is 0.901 , and the minimum value is -0.152 with a standard deviation is 0.196 . The average value of CTX variable is 2404117.643 , the minimum value is 34275 , and the maximum value is 7977823 , with a standard deviation is 2279844.351 . The last, ROA's average value is 0.084 , with minimum value is -0.040 , the maximum value is 0.402 , and the standard deviation value is 0.095 .

Table 2. Descriptive Statistics

\begin{tabular}{lcccc}
\hline & Average & Maximum & Minimum & Std Dev \\
\hline DPR & 0.387 & 1 & 0.080 & 0.199 \\
CCR & 20985.393 & 217649 & 1487 & 41847.583 \\
PYE & 7695524.286 & 26227991 & 171784 & 8295393.933 \\
SGW & 0.122 & 0.901 & -0.152 & 0.196 \\
CTX & 2404117.643 & 7977823 & 34275 & 2279844.351 \\
ROA & 0.084 & 0.402 & -0.040 & 0.095 \\
\hline
\end{tabular}

Source: secondary data, processed. 


\section{Classic Assumption Test Results}

Before performing regression analysis, first to test the classical assumption of residual normality test, multicollinearity test, autocorrelation, and heteroscedasticity test.

Based on the test results with the residual normality using the Kolmogorov-Smirnov statistics, the obtained value of $Z$ statistic of 0.847 with a significance level of 0,470 , which showed that the $Z$ value not statistically significant and have meant that data residuals are normally distributed.

Multicollinearity test examined by looking at VIF (Variance Inflation Factor). Based on Table 3, it is shown that all independent variables used have a VIF value smaller than 10 , so it can be concluded that there is no multicollinearity in the regression equation.

Table 3. Result of Multicollinearity Test

\begin{tabular}{ccc}
\hline Variable & Tolerance & VIF \\
\hline CCR & 0.759 & 1.318 \\
PYE & 0.119 & 8.374 \\
SGW & 0.930 & 1.076 \\
CTX & 0.121 & 8.237 \\
ROA & 0.931 & 1.075 \\
\hline
\end{tabular}

Source: Eviews 9.0 output

The autocorrelation test using the Dubin-Watson test, from the results of the analysis, the DurbinWatson statistical value of 2.078 was found in the range of 1.5 to 2.5 , which indicates there was no autocorrelation in the research model.

Heteroscedasticity test using the Glejser test and the results show that there is no correlation between the independent variables of the study, the complete Glejser test results shown in Table 4.

Table 4. Result of Glejser Test

\begin{tabular}{ccc}
\hline Variable & $\mathrm{t}$ & Sig. \\
\hline CCR & -1.242 & 0.220 \\
PYE & -1.020 & 0.313 \\
SGW & -1.319 & 0.193 \\
CTX & 1.342 & 0.186 \\
ROA & 1.399 & 0.192 \\
\hline
\end{tabular}

Source: Eviews 9.0 output

\section{Hypothesis Testing}

F-statistic Test

Table 5. Result of F-statistic

\begin{tabular}{ll}
\hline F-statistic & 8.323829 \\
\hline Prob(F-Statistic) & 0.000009 \\
\hline Source: Eviews 9.0 output &
\end{tabular}

Based on the F test results in Table 5, it is shown that the F-statistic value of the regression equation is 8.323829 with a p-value of 0.000009 . This shows that the variables contributed capital ratio, prior yearearnings, sales growth, corporate taxes, and return on assets together have a significant effect on dividend payout ratio.

\section{t-statistic Test}

Table 6. Result of t-statistic

\begin{tabular}{ccccc}
\hline Variable & Coefficient & Std. Error & t-Statistic & Prob. \\
\hline C & 0.235651 & 0.043444 & 5.424223 & 0.0000 \\
CCR & $-9.44 \mathrm{E}-07$ & $5.71 \mathrm{E}-07$ & -1.652336 & 0.1047 \\
PYE & $1.59 \mathrm{E}-09$ & $7.27 \mathrm{E}-09$ & 0.218514 & 0.8279 \\
SGW & 0.003081 & 0.110489 & 0.027889 & 0.9779 \\
CTX & $1.68 \mathrm{E}-08$ & $2.62 \mathrm{E}-08$ & 0.639512 & 0.5254
\end{tabular}




\begin{tabular}{ccccc}
\hline Variable & Coefficient & Std. Error & t-Statistic & Prob. \\
\hline ROA & 1.400908 & 0.228934 & 6.119260 & 0.0000 \\
\hline Source: Eviews & 9.0 output & & &
\end{tabular}

The results of the regression analysis shown in Table 5. The CCR (contributed capital ratio) variable has a p-value of 0.1047 , with Alpha 0.05 it can be concluded that $\mathrm{H} 1$ is rejected. This means that the CCR variable has no significant effect on the dividend payout ratio. The PYE (prior year-earnings) variable has a p-value of 0.8279 , with Alpha 0.05 it can be concluded that $\mathrm{H} 2$ is rejected. This means that the PYE variable has no significant effect on the dividend payout rate. The SGW variable (sales growth) has a p-value of 0.9779 , with Alpha 0.05, it can be concluded that $\mathrm{H} 3$ is rejected. This means that the SGW variable does not significantly influence the dividend payout ratio. The variable CTX (corporate taxes) has a p-value of 0.5254 , with Alpha 0.05 it can be concluded that $\mathrm{H} 4$ is rejected. This means that the CTX variable has no significant effect on the dividend payout ratio. The ROA (return on assets) variable has a p-value of 0.0000 , with Alpha 0.05 it can be concluded that $\mathrm{H} 5$ is accepted. This means that the ROA variable has a significant positive effect on the dividend payout ratio. The discussions about the results are described in the next section.

\section{DISCUSSION}

\section{Relationship of Contributed Capital Ratio to Dividend Payout Ratio}

Statistical test results show that the contributed capital ratio does not significantly influence dividend policy, which is proxied by a dividend payout ratio. These results support Anthony \& Ramesh (1992) conclusion that companies with higher unexpected capital expenditure tend to hold their capital to keep up their survival rather than pay dividends. As revealed by Megginson (1997) approaches the three main stages of a company's life cycle in determining dividend payment policies, namely the growth stage, mature stage, and decline stage. When companies are at the growth stage, they adopt a full financing position by paying no dividends at all. However, when companies mature, they apply zero dividends and hold profits. Then the company that is in the decline stage will make a dividend payment policy to attract shareholders to invest higher capital. In a decline stage, the company experienced the lowest growth even negative. To increase the growth of capital contribution must be added by giving a payment policy signal. Thus it can be concluded that the contributed capital ratio that represents the life cycle of the company does not affect dividend policy. This may happen because SRI-Kehati constituent companies are established companies with long operational history (more than 50 years on average) and most of them become the leader in their business and have attractive DPR.

\section{Relationship of Prior Year-earnings to Dividend Payout Ratio}

The findings of this study prove that prior year-earnings are not the factors that determine dividend policy. This result supports Odhiambo (2013) conclusion which examines the effect of dividends and earnings announcements on stock prices. His research conducted on 10 selected companies and found that dividend payments did not reflect shareholder value and reduced the company's resources for investment. Nzuk (2016) found investors' reactions to pre-earnings announcements. Investors decided to release shares that were underperforming and acquire shares that were more promising to pay higher income in the future. The previous year's earnings can be a signal for investors to act, but that does not mean the company will distribute dividends. When a company knows that the previous year's earnings are high, managers may think more to share their earnings with shareholders and think about more prospective company investments (Dagys \& Mladjenovic, 2010). Funds for future investments are reduced if the company shares its income with shareholders. This may happen if the company sees the limited growth opportunity and tend to be conservative, hence the present value of growth opportunities may not suitable in this case.

\section{Relationship of Sales Growth to Dividend Payout Ratio}

The growth of the company's current sales value from the previous period did not affect dividend policy decisions. This shows that, companies that grow well need more funds to finance their growth and try to keep up their earnings proportion by paying dividends equal to the previous year, or lower, or not at

JMER, 2020, 01(1), 1-12 
all. This finding is consistent with Alzomaia \& Al-Khadhiri (2013) and Khan \& Ashraf (2014) that company growth does not significantly determine dividend policy. Companies that included in the SRIKEHATI Index are groups of companies that implement good governance and have rapid growth compared to companies that are not included in this index, while dividend policy is one of corporate governance. By simply paying attention on the company on the SRI-KEHATI Index list, investors possibly more interested in their sales growth and assume they will get higher dividends. Though it is not necessarily done by the company. Gill et al. (2010) examine the factors that determine the level of dividend payments to manufacturing companies, service companies, and entire samples. They concluded that sales growth determines the standard dividend payout of service companies and companies in the entire samples, whereas, for manufacturing companies, sales growth is not significant to the standard dividend payout.

\section{Relationship of Corporate Taxes to Dividend Payout Ratio}

This empirical result shows that corporate taxes are insignificant to the dividend payout ratio which is a proxy for dividend policy. This finding is in line with the results of previous studies. Gill et al. (2010) used two proxies to measure dividend policy, namely the standard dividend payout ratio and adjusted dividend payout ratio, finding different facts from two ratios. Corporate taxes of service companies do not affect the standard dividend payout ratio, however, in manufacturing companies show a significant relationship. Then corporate taxes are insignificant against adjusted dividend payout in all companies in the manufacturing sector or service sector. A similar result was also proved by Hutagaol-Martowidjojo et al. (2019), corporate income tax does not determine the ratio of dividend payments in manufacturing companies, but not in service companies. Thus, this finding rejects the signal dividend theory. Higher corporate taxes do not necessarily imply higher earnings, specifically in recognition or amortization of deferred tax assets (DTA). If the amount of amortization is greater than the previous DTA in the balance sheet, it will raise the company's tax instead of the company's current performance. This study focused on the corporate level rather than the individual level. So, the explanation done by using the corporate perspective.

\section{Relationship of Return on Assets to Dividend Payout Ratio}

This research proves that return on assets has a positive effect on dividend policy. Return on assets is a ratio to measure a company's profitability that can determine the amount of dividend payments to shareholders. This result is consistent with Hutagaol-Martowidjojo et al. (2019); Ahmad \& Wardani (2014); and Gill et al. (2010). This gives the fact that companies that included in the SRI-KEHATI Index with a greater ROA tend to announce dividends to signal future profits. As Brigham \& Houston (2016) explained, ROA is a measure of a company's ability to generate net income from its assets. The total assets of the company indicate the size of the company. Companies with large assets will seek to maximize net income and announce higher dividends.

\section{CONCLUSION}

Corporate dividend policy is often debated by the financial expert, management's decision dividends payment has been researched empirically with varied results. This study looks at dividend policy in terms of management decisions in determining the number of dividends paid, known by calculating the dividend payout ratio. The research hypothesis states there is a positive relationship between earnings and corporate taxes on dividend policy. The research findings are contrary to the hypothesis of this study. Empirical results found that the contributed capital ratio, prior year-earnings, sales growth, and corporate taxes were not significant to the dividend payout ratio. Only return on assets has a positive effect on the dividend payout ratio. It can be concluded that companies that grow well will need more funds to cover their financing and try to maintain earnings proportion, one of the ways is by paying constant dividends, or lower, or even zero dividends. Moreover, income tax which cuts part of the company's income will reduce the company's possibility to distribute dividends.

Based on these findings, we recommend investors to pay attention to the company's profitability by measuring return on assets. A high return on assets reflects a higher level of dividend payments in the 
future. For companies, dividend payment decisions are a complex management context, so considering various aspects of finding a win-win solution between management and shareholders. There is no perfect paper, this research has a flaw that can be filled in by future research. Future research can use the new stock index's constituents such as IDX High Dividend (an index that measures the price performance of 20 stocks that have distributed cash dividends over the past 3 years and has a high dividend yield) and include other factors to determine dividend policy.

\section{REFERENCES}

Adjaoud, F., \& Ben- Amar, W. (2010). Corporate Governance and Dividend Policy: Shareholders' Protection or Expropriation? Journal of Business Finance \& Accounting, 37(5-6), 648-667. https://doi.org/10.1111/j.1468-5957.2010.02192.x

Ahmad, G. N., \& Wardani, V. K. (2014). The Effect of Fundamental Factor to Dividend Policy: Evidence in Indonesia Stock Exchange. International Journal of Business and Commerce, 4(2), $14-25$.

Ahmed, I. E. (2015). Liquidity, Profitability and the Dividends Payout Policy. World Review of Business Research, 5(2), 73-85.

Al- Malkawi, H. N. (2007). Determinants of Corporate Dividend Policy in Jordan: An Application of the Tobit Model. Journal of Economic and Administrative Sciences, 23(2), 44-70.

Allen, F., \& Michaely, R. (1995). Dividend Policy. In Handbooks in Operations Research and Management Science (9th ed., pp. 793-837).

Allen, F., \& Michaely, R. (2003). Payout Policy. In Handbook of the Economics of Finance (1st ed., pp. 337-429). Elsevier.

Alzomaia, T. S., \& Al-Khadhiri, A. (2013). Determination of Dividend Policy: The Evidence from Saudi Arabia. International Journal of Business and Social Science, 4(1), 181-192.

Anthony, J. H., \& Ramesh, K. (1992). Association between Accounting Performance Measures and Stock Prices. Journal of Accounting and Economics, 15(2-3), 203-227. https://doi.org/10.1016/0165-4101(92)90018-W

Anton, S. G. (2016). The Impact of Dividend Policy on Firm Value. A Panel Data Analysis of Romanian Listed Firms. Journal of Public Administration, Financeand Law, 10, 107-112.

Arif, A., \& Akbar, F. (2013). Determinants of Dividend Policy: A Sectoral Analysis from Pakistan. International Journal of Business and Behavioral Sciences, 3(9), 16-33.

Arnott, R. D., \& Asness, C. S. (2003). Surprise! Higher Dividends = Higher Earnings Growth. Financial Analysts Journal, 59(1), 70-87. https://doi.org/10.2469/faj.v59.n1.2504

Baker, H. K., \& Powell, G. E. (2012). Dividend Policy in Indonesia: Survey Evidence from Executives. Journal of Asia Business Studies, 6(1), 79-92. https://doi.org/10.1108/15587891211191399

Boquist, J. A., Milbourn, T. T., \& Thakor, A. V. (1998). How Do You Win the Capital Allocation Game? Sloan Management Review, 39(2), 59-71.

Brigham, E. F., \& Houston, J. F. (2016). Fundamentals of Financial Management (Ninth). Cengage Learning.

Charitou, A., Lambertides, N., \& Theodoulou, G. (2010). The Effect of Past Earnings and Dividend Patterns on the Information Content of Dividends When Earnings are Reduced. Abacus, 46(2), 153-187. https://doi.org/10.1111/j.1467-6281.2010.00314.x

Dagys, A., \& Mladjenovic, P. (2010). Stock Investing For Canadians For Dummies (3rd ed.). John Wiley \& Sons, Inc.

DeAngelo, H., DeAngelo, L., \& Skinner, D. J. (2004). Are Dividends Disappearing? Dividend Concentration and The Consolidation of Earnings. Journal of Financial Economics, 72(3), 425456. https://doi.org/10.1016/S0304-405X(03)00186-7

DeAngelo, H., DeAngelo, L., \& Stulz, R. M. (2006). Dividend policy and the earned/contributed capital mix: a test of the life-cycle theory. Journal of Financial Economics, 81(2), 227-254. https://doi.org/10.1016/j.jfineco.2005.07.005

Demirgüç-Kunt, A., \& Huizinga, H. (1999). Determinants of Commercial Bank Interest Margins and Profitability: Some International Evidence. The World Bank Economic Review, 13(2), 379-408. https://doi.org/10.1093/wber/13.2.379 
Dietrich, A., \& Wanzenried, G. (2014). The Determinants of Commercial Banking Profitability in Low, Middle-, and High-income Countries. The Quarterly Review of Economics and Finance, 54(3), 337-354. https://doi.org/10.1016/j.qref.2014.03.001

Fleischer, G. A. (1969). Capital Allocation Theory: The Study of Investment Decisions (No. HG4028). Appleton-Century-Crofts.

Gill, A., Biger, N., \& Tibrewala, R. (2010). Determinants of Dividend Payout Ratios: Evidence from United States. The Open Business Journal, 3(1), 8-14.

Hashemijoo, M., Ardekani, A. M., \& Younesi, N. (2012). The Impact of Dividend Policy on Share Price Volatility in the Malaysian Stock Market. Journal of Business Studies Quarterly, 4(1).

Hatta, A. J. (2002). Faktor-faktor yang Mempengaruhi Kebijakan Dividen: Investigasi Pengaruh Teori Stakeholder. Jurnal Akuntansi Dan Auditing Indonesia, 6(2).

Hussainey, K., Mgbame, C. O., \& Chijoke- Mgbame, A. M. (2011). Dividend Policy and Share Price Volatility: UK Evidence. Journal of Risk Finance, 12(1), 57-68. https://doi.org/10.1108/15265941111100076

Hutagaol-Martowidjojo, Y., Joachim, H., \& Anggraeni, D. (2019). The role of earnings and tax on dividend policy of Indonesian listed firms. Jurnal Keuangan Dan Perbankan, 23(1), 29-42. https://doi.org/10.26905/jkdp.v23i1.2581

Imran, K. (2011). Determinants of Dividend Payout Policy: A Case of Pakistan Engineering Sector. The Romanian Economic Journal, 14(41), 47-60.

Indonesia Stock Exchange (IDX). (2019). IDX Fact Book.

Ishaq, M., Amin, K., \& Khan, F. (2018). Factors Determining the Dividend Payout in the Cement Sector of Pakistan. City University Research Journal, 8(2), 171-186.

Jabbouri, I. (2016). Determinants of corporate dividend policy in emerging markets: Evidence from MENA stock markets. Research in International Business and Finance, 37(May), 283-298. https://doi.org/10.1016/j.ribaf.2016.01.018

Khadafi, M., Heikal, M., \& Ummah, A. (2014). Influence Analysis of Return on Assets (ROA), Return on Equity (ROE), Net Profit Margin (NPM), Debt to Equity Ratio (DER), and Current Ratio (CR), Against Corporate Profit Growth in Automotive in Indonesia Stock Exchange. International Journal of Academic Research in Business and Social Sciences, 4(12), 219-226.

Khan, W., \& Ashraf, N. (2014). In Pakistani Service Industry: Dividend Payout Ratio as Function of some Factors. International Journal of Academic Research in Accounting, Finance and Management Sciences, 4(1), 390-396.

Kighir, A. E., Omar, N. H., \& Mohamed, N. (2015). Corporate Cash Flow and Dividends Smoothing: A Panel Data Analysis at Bursa Malaysia. Journal of Financial Reporting and Accounting, 13(1), 2-19. https://doi.org/10.1108/JFRA-09-2013-0072

Megginson, W. L. (1997). Corporate Finance Theory. Addison-Wesley.

Miller, M. H., \& Modigliani, F. (1961). Dividend Policy, Growth, and The Valuation of Shares. The Journal of Business, 34(4), 411-433.

Munawir. (2004). Analisa Laporan Keuangan (4th ed.). Liberty.

Myers, M., \& Bacon, F. (2004). The Determintants of Corporate Dividend Policy. Academy of Accounting and Financial Studies Journal, 8(3), 17-28.

Needles, B. E., Powers, M., \& Crosson, S. V. (2010). Principles of Accounting (11th ed.). Cengage Learning.

Nzuk, D. M. (2016). Effect of Semi-annual Earning Announcement on Share Price Performance of Financial Service Firms Listed at the Nairobi Stock Exchange. KCA University.

Odhiambo, F. O. (2013). The Influence of Dividends and Earnings Announcement on Shareholders' Value of Companies Listed at the Nairobi Securities Exchange. University of Nairobi.

Osegbue, I. F., Ifurueze, M., \& Ifurueze, P. (2014). An Analysis of the Relationship between Dividend Payment and Corporate Performance of Nigerian. Global Business and Economics Research Journal, 3(2), 75-95.

Pranata, D., \& Pujiati, D. (2015). The Effect of Liquidity, Profitability, Sales growth, and Dividend Policy on Stock Prices after the Implementation of IFRS. The Indonesian Accounting Review, 5(2), 169. https://doi.org/10.14414/tiar.v5i2.647

Rizqia, D. A., \& Sumiati, S. A. (2013). Effect of Managerial Ownership, Financial Leverage, 
Profitability, Firm Size, and Investment Opportunity on Dividend Policy and Firm Value. Research Journal of Finance and Accounting, 4(11), 120-130.

Setiawan, D., \& Phua, L. K. (2013). Corporate Governance and Dividend Policy in Indonesia. Business Strategy Series, 14(5/6), 135-143. https://doi.org/10.1108/BSS-01-2013-0003

Tahir, M., \& Mushtaq, M. (2016). Determinants of Dividend Payout: Evidence from listed Oil and Gas Companies of Pakistan. Journal of Asian Finance, Economics and Business, 3(4), 25-37. https://doi.org/10.13106/jafeb.2016.vol3.no4.25

Thanatawee, Y. (2011). Life-Cycle Theory and Free Cash Flow Hypothesis: Evidence from Dividend Policy in Thailand. International Journal of Financial Research, 2(2), 52-60.

Winarno, W. W. (2017). Analisis Ekonometrika dan Stastiska dengan Eviews (5th ed.). STIM YKPN. 